\title{
PENGARUH PERUBAHAN PENJUALAN, ASSET INTENSITY, PROFITABILITY, SIZE, DAN LEVERAGE TERHADAP COST STICKINESS
}

\author{
Evelyn \\ Fakultas Magister Ekonomi, Universitas Tarumanagara, Jakarta \\ Email: evelyne_joe@yahoo.com
}

\begin{abstract}
This study aims to obtain empirical evidence on the effect of changes in sales, asset intensity, profitability, firm size, and debt level to cost stickiness on all companies listed in Indonesia Stock Exchange for 20122016 period. The number of sample companies used in this study are 150 companies. The result of this study indicates that on the condition of net sales increase, the increase of SGA cost is higher than the decrease of SGA cost at the time of net sales decrease, asset intensity has a significant positive effect on cost stickiness, profitability has no significant effect on cost stickiness, firm size has no significant effect on cost stickiness, and debt level has a significant negative effect on cost stickiness.
\end{abstract}

Keywords: Cost Stickiness, Asset Intensity, Profitability, Sales Changes, Firm Size

ABSTRAK

Penelitian ini bertujuan untuk mendapatkan bukti empiris mengenai pengaruh perubahan penjualan, asset intensity, profitability, ukuran perusahaan, dan tingkat hutang terhadap cost stickiness pada semua perusahaan yang terdaftar di bursa efek indonesia pada periode tahun 2012-2016. Jumlah sampel perusahaan yang digunakan dalam penelitian ini adalah 150 perusahaan. Hasil penelitian ini menunjukan bahwa pada kondisi penjualan bersih meningkat, kenaikan biaya SGA lebih tinggi dibandingkan penurunan biaya SGA pada saat penjualan bersih menurun, asset intensity berpengaruh positif signifikan terhadap cost stickiness, profitability tidak mempunyai pengaruh yang signifikan terhadap cost stickiness, ukuran perusahaan tidak mempunyai pengaruh signifikan terhadap cost stickiness, dan tingkat hutang berpengaruh negatif signifikan terhadap cost stickiness.

Kata kunci: Cost Stickiness, Asset Intensity, Profitability, perubahan penjualan dan ukuran perusahaan

\section{PENDAHULUAN}

Latar Belakang

Ketidakstabilan perekonomian ini diakibatkan oleh tidak adanya kepastian mengenai tingkat permintaan atas produk yang dihasilkan oleh perusahaan. Manajemen perusahaan harus dapat menentukan komitmen sumber daya yang nantinya akan mempengaruhi struktur jangka pendek dari mix cost (bauran antara biaya tetap/fixed cost dengan biaya variabel/variable cost)

Menurut pandangan akuntansi tradisional, jika perusahaan menghadapi tingkat ketidakpastian tingkat permintaan yang tinggi, maka perusahaan perlu mengatur agar struktur biayanya lebih banyak berisi biaya yang bersifat jangka pendek yang tidak rigid, dengan mengurangi biaya tetap dan menambah biaya variabel (Banker et al., 2014: 1).

Perilaku sticky cost akan terjadi apabila terdapat respon biaya terhadap peningkatan aktivitas secara signifikan lebih kuat dibandingkan dengan respon overhead cost ketika terjadi penurunan volume aktivitas (Cooper dan Kaplan, 1998). Sehingga terdapat dugaan bahwa ketika aktivitas menurun maka terjadi perilaku sticky cost pada beberapa biaya tertentu.

\section{Kajian Teori}

Teori yang berkaitan dengan cost stickiness adalah:

1. $\quad$ The Deliberate Decision Theory

Deliberate Decision Theory atau teori keputusan yang disengaja adalah salah satu teori yang dapat digunakan untuk menjelaskan cost stickiness. Suatu biaya akan menjadi 
sticky dikarenakan keputusan yang dibuat oleh para manajer secara sengaja dimana para manajer akan sengaja membuat keputusan untuk menyesuaikan sumber daya yang dimiliki dengan aktivitas perusahaan (Anderson et al., 2003; Anderson et al., 2005). Salah satu pendorong utama sticky cost adalah keputusan manajer yang disengaja yang berusaha meningkatkan keuntungan jangka panjang berdasarkan perkiraan penjualan masa depan mereka.

\section{Perilaku Biaya (Cost Behavior)}

Perilaku biaya atau yang dikenal dengan cost behavior, adalah hubungan antara terjadinya biaya dengan perubahan dalam aktivitas bisnis, atau bagaimana biaya secara total berubah saat cost drivers berubah. Ada 2 jenis biaya yang biasa dikenal dalam dunia akuntansi, yaitu biaya variabel (variable cost) dan biaya tetap (fixed cost).

Biaya variabel (variable cost) adalah biaya yang secara total berubah sejalan dengan perubahan dalam tingkatan aktivitas bisnis dalam cakupan waktu yang relevan, dan biaya yang secara total tidak terpengaruh dengan perubahan tingkatan aktivitas perusahaan dalam cakupan waktu yang relevan disebut dengan biaya tetap (fixed costs) (Hammer et al, 1994: 40; Blocher et al, 2010: 67; Islahuzzaman, 2012: 150, 487). Biaya variable hanya relevan apabila perusahaan dapat mengubah tingkat produksi seketika dalam jangka waktu yang tertentu. Dalam kenyataannya, perubahan tingkat produksi yang dilakukan oleh manajemen akan diikuti oleh komitmen jangka panjang yang tidak dapat dengan mudah diubah atau dibatalkan.

\section{Cost Stickiness}

Perilaku sticky cost pertama kali diperkenalkan oleh Malcolm (1991) yang menemukan bahwa beberapa biaya cenderung tidak mudah disesuaikan (fixed cost). Hal ini akan menimbulkan masalah ketika aktivitas naik kemudian diikuti dengan biaya yang naik namun ketika aktivitas menurun, penurunam biaya tidaklah proposional.

Perilaku sticky cost akan terjadi apabila terdapat respon biaya terhadap peningkatan aktivitas secara signifikan lebih kuat dibandingkan dengan respon overhead cost ketika terjadi penurunan volume aktivitas (Cooper dan Kaplan, 1998). Sehingga terdapat dugaan bahwa ketika aktivitas menurun maka terjadi perilaku sticky cost pada beberapa biaya tertentu. Penelitian lebih mendalam kemudian dilakukan oleh Anderson et al (2003) yang mengakui adanya penyesuaian sumber daya yang dilakukan oleh manajer saat terjadi perubahan aktivitas terkait perubahan permintaan. Perilaku sticky cost dapat dikenali oleh manajer yang kemudian akan dikendalikan oleh manajer dengan mempertimbangkan sensitivitas perubahan biaya tertentu.

Anderson et al (2003) mengatakan bahwa penurunan biaya yang terjadi ketika penjualan dan aktivitas menurun, harus dapat dipastikan oleh manajer apakah penurunan tersebut bersifat sementara atau akan berlangsung lama. Dalam kondisi tersebut, perilaku sticky cost akan terjadi apabila manajer memilih untuk mempertahankan sumber daya yang tak terpakai daripada melakukan penyesuaian terhadap kondisi tersebut.

Apabila mempertahankan sumber daya yang tak terpakai adalah cara yang dipilih oleh manajer, maka biaya Selling, General, and Administrative (SG\&A) akan tetap besar walaupun terjadi penuruan penjualan. Karena untuk mempertahankan sumber daya yang tak terpakai membutuhkan biaya yang besar sehingga hal ini akan berdampak pada Selling, General, and Administrative costs $(S G \& A)$ yang biaya secara totalnya akan tetap besar meskipun terjadi penurunan penjualan.

Sehingga dapat disimpulkan bahwa, cost stickiness adalah perilaku biaya yang kaku dimana walaupun penjualan turun, biaya tersebut susah untuk turun tetapi apabila penjualan naik, maka biaya tersebut akan ikut naik. Contoh biaya yang termasuk dalam 
golongan sticky cost adalah fixed cost seperti yang termasuk dalam Selling, General, and Administrative cost.

\section{4. $\quad$ Asset Intensity}

Dalam dunia akuntansi, aset terdiri dari (1) Aset Lancar, (2) Aset Jangka Panjang. Sebagian besar perusahaan mengandalkan pembiayaan dengan (1) modal pemiliki (owner's equity), dan (2) pinjaman dalam rangka menyediakan aset bagi kebutuhan operasionalnya. Perusahaan-perusahaan memiliki proporsi aset dan pembiayaan yang berbeda-beda tergantung dari kebutuhan masing-masing perusahaan, dan perbedaan-perbedaan ini dapat menjadi faktor yang mempengaruhi perilaku biaya, sehingga biaya tidak bergerak secara simetris mengikuti tingkat aktivitas bisnis perusahaan.

\section{Profitability}

Profitabilitas merupakan kemampuan perusahaan dalam menghasilkan laba selama periode tertentu, biasanya dilihat pertahun. Rasio profitabilitas digunakan untuk mengetahui kemampuan sebuah perusahaan dalam menghasilkan laba selama periode tertentu (biasanya pertahun) dan juga gambaran tentang tingkat efektivitas manajemen dalam melaksanakan kegiatan operasinya dalam periode yang sama. Ada beberapa cara untuk mengukur profitabilitas dalam menganalisis keuangan, antara lain: Margin Laba (Profit Margin), Pengembalian atas Aset (Return on Assets - ROA), Pengembalian atas Ekuitas (Return on Equity - ROE) dan Rasio Pembayaran Dividen (Payout Ratio) (Brealey, Myers, Marcus, 2008).

\section{Ukuran Perusahaan}

Dilihat dari ukurannya, perusahaan dibagi menjadi 3, yaitu perusahaan besar, menengah, dan kecil, dimana perusahaan yang besar memiliki sistem manajemen yang lebih kompleks dan memiliki laba yang lebih tinggi. Oleh sebab itu, perusahaan yang besar memiliki risiko serta masalah yang lebih kompleks serta akan dikenakan biaya politis yang lebih tinggi daripada perusahaan perusahaan kecil dan menengah.

\section{Tingkat hutang}

Debt covenant (kontrak utang) merupakan perjanjian untuk melindungi kreditur atau pihak yang memberikan pinjaman dari tindakan-tindakan manajer yang mendahulukan kepentingan perusahaan tanpa memperhitungkan kepentingan kreditur. Debt covenant hypothesis memprediksi bahwa pihak manajerial ingin meningkatkan asset dan laba nya untuk mengurangi biaya renegosiasi kontrak utang yang telah disetujui sebelumnya ketika perusahaan akan memutuskan perjanjian hutang tersebut. Debt covenant disini akan dihitung menggunakan leverage. Tingkat hutang dalam struktur modal akan mengurangi distorsi perilaku biaya yang berasal dari diskresi manajemen.

Kerangka hipotesis dalam penelitian ini seperti digambarkan dibawah ini: 


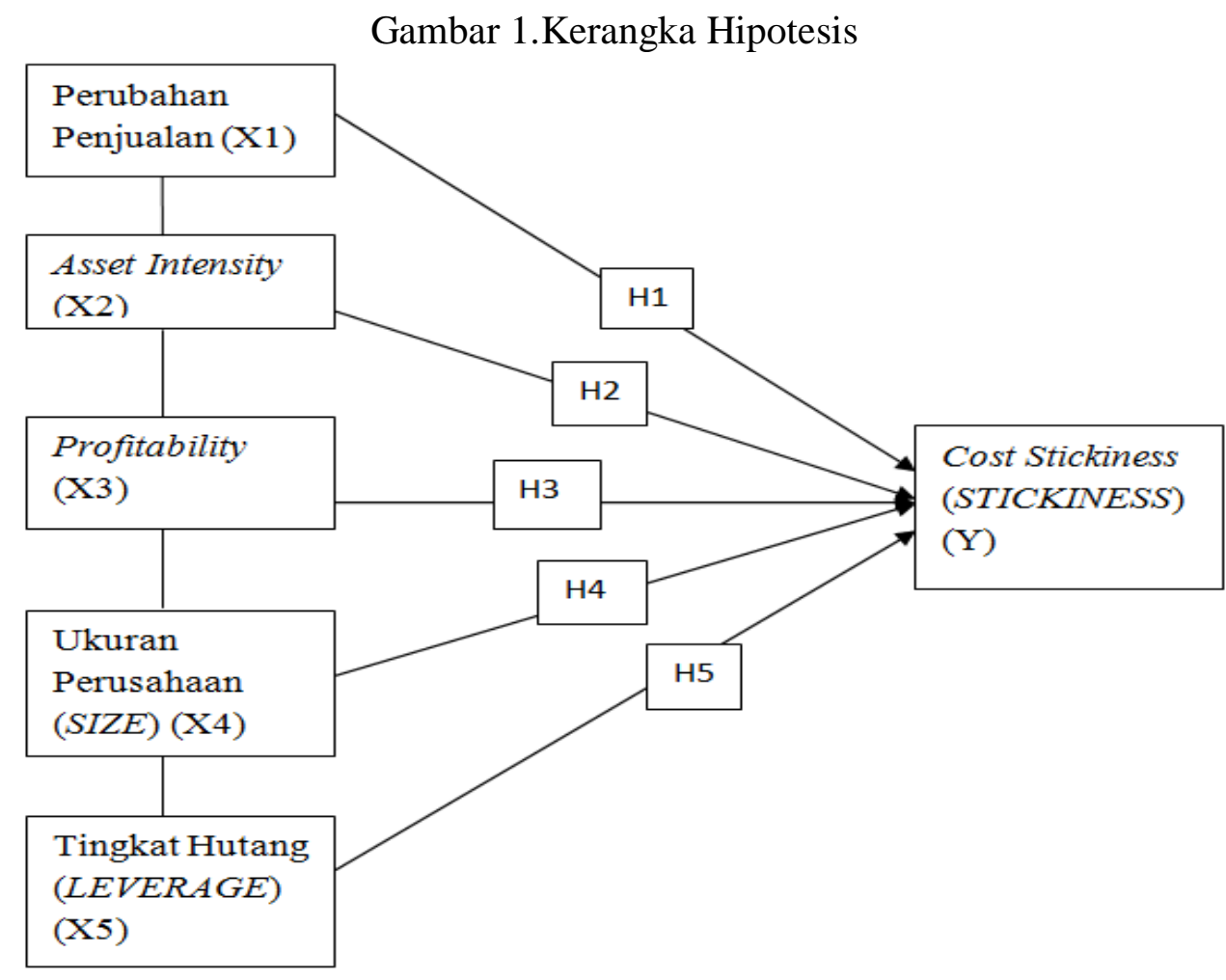

Hipotesis dari model yang dibangun di atas adalah sebagai berikut:

H1 : Perubahan penjualan berpengaruh positif terhadap cost stickiness.

$\mathrm{H} 2$ : Asset intensity berpengaruh positif terhadap cost stickiness.

H3 : Profitability berpengaruh negatif terhadap cost stickiness.

H4 : Ukuran perusahaan positif berpengaruh terhadap cost stickiness.

H5 : Tingkat hutang berpengaruh negatif terhadap cost stickiness.

\section{METODE PENELITIAN}

Penelitian ini termasuk ke dalam penelitian deskriptif. Objek penelitian dalam penelitian ini terdiri dari variabel independen, dan variabel dependen. Obyek yang akan diteliti dalam penelitian ini adalah: perubahan penjualan, asset intensity, profitability, ukuran perusahaan dan tingkat hutang.

Alasan dari pemilihan faktor-faktor yang mempengaruhi cost stickiness sebagai objek penelitian adalah karena penelitian ini ingin mengetahui apakah faktor-faktor tersebut benar mempengaruhi cost stickiness. Unit analisis pada penelitian ini adalah perusahaan non keuangan yang terdaftar di Bursa Efek Indonesia pada tahun 2012-2016.

Penelitian ini menggunakan eviews versi 8 dengan Uji Statistik Deskriptif untuk menguji data sampel. Untuk uji hipotesis, penelitian ini menggunakan Robust least Square $\left(\mathrm{R}^{2}\right)$, dan Uji hipotesis parsial.

\section{HASIL DAN PEMBAHASAN}

\section{A. Hasil Pengujian dengan Robust Least Square}

Dependent Variable: STICKINESS__ Y_

Method: Robust Least Squares

Date: 01/07/18 Time: 18:52

Sample (adjusted): 1750

Included observations: 750 after adjustments

Method: M-estimation 
M settings: weight $=$ Bisquare, tuning $=4.685$, scale $=$ MAD (median centered)

Huber Type I Standard Errors \& Covariance

\begin{tabular}{crlll}
\hline \hline \multicolumn{1}{c}{ Variable } & Coefficient & Std. Error & z-Statistic & Prob. \\
\hline \hline C & 0.030883 & 0.036444 & 0.847421 & 0.3968 \\
SALES_CHG_X1_- & 0.206643 & 0.009984 & 20.69698 & 0.0000 \\
ASSET_X2_- & 0.258802 & 0.014293 & 18.10688 & 0.0000 \\
ROE_X3_- & $3.50 E-05$ & $9.73 E-05$ & 0.359739 & 0.7190 \\
SIZE_X4__ & -0.000145 & 0.001266 & -0.114265 & 0.9090 \\
TINGKAT_HUTANG & & & & \\
_X5_ & -0.005555 & 0.002456 & -2.261604 & 0.0237 \\
\hline \hline & Robust Statistics & \\
\hline \hline R-squared & 0.187304 & Adjusted R-squared & 0.181842 \\
Rw-squared & 0.572027 & Adjust Rw-squared & 0.572027 \\
Akaike info criterion & 1075.618 & Schwarz criterion & 1105.483 \\
Deviance & 2.990448 & Scale & 0.052971 \\
Rn-squared statistic & 1103.890 & Prob (Rn-squared stat.) & 0.000000 \\
\hline \hline & Non-robust Statistics & \\
\hline \hline
\end{tabular}

Dalam pengujian hipotesis menggunakan Robust Least Square, kita dapat melihat apakah hipotesis penelitian diterima atau ditolak dari nilai Prob. yang ada dalam tabel untuk masing-masing variabel. Apabila nilai probabilitas $<0,05$, maka variabel independen mempunyai pengaruh signifikan terhadap variabel dependen. Sedangkan untuk arah dan besarnya pengaruh varibel independen terhadap dependen dapat kita lihat dari koefisiennya.

\section{Hipotesis 1 : Pada kondisi penjualan bersih meningkat, kenaikan biaya SGA lebih tinggi dibandingkan penurunan biaya SGA pada saat penjualan bersih menurun}

Nilai probabilitas untuk perubahan penjualan (X1= Sales Change) adalah 0,0000 dengan nilai koefien regresinya 0,206643. Nilai probabilitas tersebut lebih kecil dari 0,05 dan tanda dari koefisien adalah positif. Ini sesuai dengan perumusan hipotesis yang ada. Artinya, yaitu: Pada kondisi penjualan bersih meningkat, kenaikan biaya SGA lebih tinggi dibandingkan penurunan biaya SGA pada saat penjualan bersih menurun. Sehingga dapat kita simpulkan, bahwa apabila penjualan bersih meningkat sebesar satu satuan, maka besarnya cost stickiness akan meningkat sebesar 0,206643 satuan.

\section{Hipotesis 2 : Asset intensity berpengaruh positif terhadap cost stickiness.}

Nilai probabilitas untuk asset intensity (X2=Asset) adalah 0,0000. Nilai tersebut lebih kecil dari 0,05 sehingga ini berarti asset intensity mempunyai pengaruh signifikan terhadap cost stikiness. Besarnya koefisien untuk asset intensity adalah 0,258802. Karena nilai koefisien regresi positif, maka dapat dikatakan bahwa asset intensity berpengaruh positif terhadap cost stickiness. Ini berarti hipotesis untuk asset intensity diterima. Kesimpulannya: asset intensity berpengaruh positif signifikan terhadap cost stickiness sebesar 0,258802. Artinya, apabila asset intensity meningkat sebesar satu satuan, maka cost stickiness akan meningkat sebesar 0,258802 satuan. 


\section{Hipotesis 3 : Profitability berpengaruh negatif terhadap cost stickiness.}

Nilai probabilitas untuk profitability yang diproksikan dengan $\mathrm{ROE}(\mathrm{X} 3=\mathrm{ROE})$ adalah 0,7190. Nilai tersebut lebih besar dari 0,05 sehingga profitability tidak memilki pengaruh yang signifikan terhadap cost stickiness. Koefisien regresi yang dihasilkan untuk profitability adalah 0,000035 . Karena tanda pada koefisien adalah positif, sehingga profitability berpengaruh positif terhadap cost stickiness. Ini berarti hipotesis untuk profitability ditolak. Profitability tidak mempunyai pengaruh yang signifikan terhadap cost stickiness ini dikarekan manajemen tidak akan mengambil keputusan apapun ketika perusahaan mengalami kenaikan keuntungan sehingga keputusan manajemen yang berdampak pada cost stickiness tidak diambil.

\section{Hipotesis 4 : Ukuran perusahaan positif berpengaruh terhadap cost stickiness.}

Nilai probabilitas untuk ukuran perusahaan $(\mathrm{X} 4=S I Z E)$ adalah 0,9090 . Nilai tersebut lebih besar dari 0,05 sehingga ukuran perusahaan tidak mempunyai pengaruh yang signifikan terhadap cost stickiness. Besarnya koefisien untuk ukuran perusahaan adalah $-0,000145$. Karena tanda dari koefisien yang dihasilkan adalah negatif maka ukuran perusahaan berpengaruh negatif terhadap cost stickiness, ini berarti hipotesis untuk ukuran perusahaan ditolak. Artinya, yaitu: ukuran perusahaan mempunyai pengaruh negatif yang tidak signifikan terhadap cost stickiness. Karena cost stickiness muncul karena adanya keputusan manajemen mengenai pembuangan asset ketika penjualan menurun. Walaupun perusahaan termasuk ukuran kecil maupun besar, apabila penjualan tidak mengalami perubahan, maka manajemen tidak akan mengambil keputusan mengenai sumber daya yang harus disesuaikan kepemilikannya dengan penjualan yang ada sehingga tidak akan berpengaruh terhadap cost stickiness.

\section{Hipotesis 5 : Tingkat hutang berpengaruh negatif terhadap cost stickiness.}

Nilai Prob. untuk tingkat hutang yang diproksikan dengan leverage (X5= Leverage) adalah 0,0237. Nilai tersebut lebih kecil dari 0,05 maka hipotesis untuk tingkat hutang diterima. Serta besarnya koefisien untuk tingkat hutang adalah -0,005555. Ini berarti pengaruh tingkat hutang terhadap cost stickiness adalah tidak searah (berlawan) sebesar 0,005555. Artinya, yaitu: tingkat hutang berpengaruh negatif signifikan terhadap cost stickiness. Sehingga dapat disimpulkan bahwa apabila tingkat hutang perusahaan meningkat sebesar satu satuan, maka cost stickiness dalam perusahaan tersebut akan menurun sebesar 0,005555 satuan. Sebaliknya, apabila tingkat hutang suatu perusahaan menurun sebesar satu satuan, maka cost stickiness dalam perusahaan akan meningkat sebesar 0.005555 satuan.

\section{B. Analisis Regresi Berganda}

Model regresi yang dihasilkan dalam penelitian ini adalah:

$\mathrm{Y}=0,030883+0,206643 \mathrm{X} 1+0.258803 \mathrm{X} 2+0,000035 \mathrm{X}_{3}-0,000145 \mathrm{X}_{4}-0,0055555 \mathrm{X}_{5}+$ 0.116831

\begin{tabular}{ll}
$\mathrm{c}$ & $=$ Nilai intercept atau konstanta \\
$\mathrm{b}_{1} \mathrm{~b}_{2} \mathrm{~b}_{3} \mathrm{~b}_{4} \mathrm{~b}_{5}$ & \multicolumn{1}{c}{ Slope Coefficient } \\
$\mathrm{Y}$ & $=$ Cost stickiness \\
$\mathrm{X}_{1}$ & $=$ Perubahan penjualan \\
$\mathrm{X}_{2}$ & $=$ Asset Intensity \\
$\mathrm{X}_{3}$ & $=$ Profitability \\
$\mathrm{X}_{4}$ & $=$ Ukuran Perusahaan
\end{tabular}


$\begin{array}{ll}\mathrm{X}_{5} & =\text { Tingkat Hutang } \\ \mathrm{e} & =\text { error }\end{array}$

Pada persamaan di atas, dapat kita lihat, bahwa apabila semua variabel independen (perubahan penjualan, asset intensity, profitability, ukuran perusahaan dan tingkat hutang) sebesar nol, maka cost stickiness mempunyai nilai sebesar 0,147714 dimana terdapat proporsi eror sebesar 0,116831 .

\section{Diskusi}

Dari hasil pengujian Hipotesis dengan uji Robust least Square menunjukkan bahwa:

1. Pada kondisi penjualan bersih meningkat, kenaikan biaya SGA lebih tinggi dibandingkan penurunan biaya SGA pada saat penjualan bersih menurun.

2. Asset intensity berpengaruh positif signifikan terhadap cost stickiness.

3. Profitability tidak mempunyai pengaruh yang signifikan terhadap cost stickiness ini dikarekan manajemen tidak akan mengambil keputusan apapun ketika perusahaan mengalami kenaikan keuntungan sehingga keputusan manajemen yang berdampak pada cost stickiness tidak diambil.

4. Ukuran perusahaan tidak mempunyai pengaruh signifikan terhadap cost stickiness. Karena cost stickiness muncul karena adanya keputusan manajemen mengenai pembuangan asset ketika penjualan menurun. Walaupun perusahaan termasuk ukuran kecil maupun besar, apabila penjualan tidak mengalami perubahan, maka manajemen tidak akan mengambil keputusan mengenai sumber daya yang harus disesuaikan kepemilikannya dengan penjualan yang ada sehingga tidak akan berpengaruh terhadap cost stickiness.

5. Tingkat hutang berpengaruh negatif signifikan terhadap cost stickiness.

Tetapi hasil dari penelitian ini memiliki R-Square yang kecil, sehingga hasil penelitian ini masih belum dapat menyimpulkan bahwa hasil analisis di atas dapat kita simpulkan untuk semua perusahaan yang terdaftar di BEI pada tahun 2012-2016 kecuali perusahaan di bidang keuangan.

\section{KESIMPULAN DAN SARAN}

Didalam penelitian ini masih terdapat banyak kekurangan dan belum sempurna. Penelitian ini memiliki beberapa keterbatasan antara lain sebagai berikut:

1. Pada penelitian ini periode pengamatan yang digunakan hanya lima tahun, yaitu dari tahun 2012-2016

2. Pada penelitian ini hanya dilakukan sebatas variabel perubahan penjualan, asset intensity, profitability, ukuran perusahaan dan tingkat hutang walaupun masih banyak variabel independen lainnya yang masih dapat diteliti.

3. Cakupan penelitian pada penelitian ini hanya pada proksi-proksi yang umum digunakan. Untuk variabel-variabel dependen di penelitian ini mempunyai cukup beragam proksi yang dapat digunakan tetapi peneliti hanya menggunakan satu proksi untuk setiap variabel.

\section{REFERENSI}

Alfian dan Sabeni. (2013). Analisis Faktor-Faktor yang Berpengaruh Terhadap Pemilihan Konservatisme Akuntansi. Diponegoro Journal Of Accounting. 2. (3). 1-10

Anderson, Mark C. Banker, Rajiv D. dan Janakiraman, Surya N., (2003), "Are Selling, General and Administrative Costs sticky?", Journal of Accounting Research. 41. (1).

Anderson, MC., Banker, RD., dan Janakiraman, SN., Huang, R., (2007), "Cost Behavior and Fundamental Analysis of SG\&A Costs”, AAA 2007 Management Accounting 
Section (MAS) Meeting Paper.

Canon, JN., (2011), "Determinants of 'sticky Costs': An Analysis of Cost Behavior Using United States Air Transportation Industry Data", AAA 2012 Management Accounting Section (MAS) Meeting paper. Available at SSRN: http://ssrn.com/abstract $=1895615$

Cooper, R. dan R. Kaplan, (1998), The Design of Cost Management System: Text, Cases, and Readings, Upper Saddle River, NJ: Prentice Hall

Dewi A, A, K., (2012), Apakah kelengketan biaya terjadi pada peruahaan manufaktur di Indonesia", Working paper, Universitas Kristen Satya Wacana Institusional Resipatory Available at http://resipatory.library.uksw.edu/handle/123456789/1148

Fiist, Pamplona, Silva, dan Zonatto. (2016). Sticky cost in cost behavior of the largest companies in Brzil, Chille and Mexico. Contaduria y Administacion. 61. 682-704.

Lubis, Arfan Ikhsan. (2010). Akuntansi Keperilakuan, Edisi 2. Jakarta: Salemba Empat.

Mimba, Rasmini, dan Setiawati. (2017). Perilaku Cost Stickiness dalam kompensasi eksekutif bank BUMN dan Non BUMN yang terdaftar di bursa efek Indonesia. EJurnal Ekonomi dan Bisnis Universitas Universitas Udayana. 6. (5). 1817-1848

Mardika, Dhoni Rizky Widya dan Sunarto, Hari. (2015). Bukti Dan Tingkatan Perilaku Sticky Cost Pada Berbagai Ukuran Perusahaan Manufaktur. Financial Management.

Nugroho, Paskah, I dan Endarwati, Wulan., (2013), "Do the Cost Stikiness in The Selling, General, and Administrative Costs Occur in Manufacturing Companies in Indonesia?", Simposium Nasional Akuntansi 16, Manado

Sarwono, Jonathan (2016). Prosedur-prosedur Analisis Populer Aplikasi Riset Skripsi dan Tesis dengan EViews. Gava Media. Yogyakarta.

Susilo, Eko. (2016). Analisis Perilaku Sticky Cost Dan Pengaruhnya Terhadap Prediksi Laba Menggunakan Model Cost Variability Dan Cost Stickiness (Cves) Pada Emiten Di BEI Untuk Industri Manufaktur. Akademi Akuntansi Keuangan dan Perbankan Indonesia Jurnal Ilmiah Revenue. 2. (2). 1-11

Weiss, D., (2010), "Cost Behavior and Analysis' Earning Forecast". The Accounting Review. 85. 4.

Windyastuti dan Biyanto, Frasto., (2005), Analisis Perilaku Kos: Stickiness Kos Pemasaran, Administrasi \& Umum Pada Penjualan Bersih (Studi Empiris Perusahaan yang Terdaftar di BEJ. SNA VIII, Solo.

Yasukata, K., dan Kajiwara, T., (2011), Are "sticky Costs" the Result of Deliberate Decision of Managers? Working paper, Available at SSRN: http://ssrn.com/abstract $=1444746$ 